\title{
Cytomegalovirus infection in renal transplantation: clinical aspects, management and the perspectives
}

\author{
Infecção pelo citomegalovírus no transplante de rim: aspectos clínicos, manejo e perspectivas
}

\author{
Lúcio Roberto Requião-Moura ${ }^{1}$, Ana Cristina Carvalho de Matos ${ }^{1}$, Alvaro Pacheco-Silva ${ }^{2}$
}

\begin{abstract}
Cytomegalovirus infection is one of most frequent infectious complications after renal transplantation, and can be classified as primo-infection, when the transmission occurs through the graft, or reactivation, when the recipient is cytomegalovirus seropositive. After transplantation, cytomegalovirus can appear as an infection, when the patient presents with evidence of viral replication without symptoms or disease, which has two clinical spectra: typical viral syndrome or invasive disease, which is a less common form. Their effects can be classified as direct, while the disease is developed, or indirect, with an increase of acute rejection and chronic allograft dysfunction risks. Diagnosis must be made based on viremia by one of the standardized methods: antigenemia or PCR, which is more sensitive. The risk factors related to infection after transplantation are the serologic matching (positive donor and negative recipient) and anti-lymphocyte antibody drugs. One of the strategies to reduce risk of disease should be chosen for patients at high risk: preemptive treatment or universal prophylaxis. Recent clinical research has described ganciclovir resistance as an emergent problem in management of cytomegalovirus infection. Two types of mutation that cause resistance were described: UL97 (most frequent) and UL54. Today, sophisticated methods of immunologic monitoring to detect specific T-cell clones against cytomegalovirus are used in clinical practice to improve the management of high-risk patients after renal transplantation.
\end{abstract}

Keywords: Cytomegalovirus; Kidney transplantation/complications; Kidney transplantation/physiopathology; Kidney transplantation/trends

\section{RESUMO}

A infecção pelo citomegalovírus é uma das principais complicações após o transplante de rim, podendo ser classificada em primoinfecção, quando a transmissão ocorre por meio do enxerto, ou em reativação, quando o receptor é soropositivo. Do ponto de vista clínico, pode se apresentar como infecção, na ausência de sintomas, ou como doença, com dois diferentes espectros: a síndrome viral típica ou, menos comumente, a doença invasiva. Os efeitos podem ser diretos, que é 0 desenvolvimento da doença, ou indiretos, como aumento no risco de rejeição aguda e de disfunção crônica do enxerto. 0 diagnóstico deve ser feito por pesquisa de viremia por meio de um dos dois métodos padronizados: antigenemia ou PCR - sendo essa última a mais sensível. Os fatores de risco relacionados com a infecção após o transplante são o match sorológico (doador positivo e receptor negativo) e o uso de anticorpos antilinfócitos. Uma das estratégias de redução de risco de doença deve ser escolhida após 0 transplante nos pacientes de alto risco: tratamento preemptivo ou profilaxia. Recentemente, linhas de pesquisa clínica têm apontado a resistência ao ganciclovir como um problema emergente no manejo da infecção pelo citomegalovírus. Duas formas de mutação que causam resistência são descritas: UL97, que é a mais frequente, e a UL54. Atualmente, sofisticados métodos de monitorização imunológica, como a detecção de clones específicos de células T contra o citomegalovírus podem ser utilizados na prática clínica para o melhor manejo após o transplante renal dos pacientes de alto risco.

Descritores: Citomegalovírus; Transplante de rim/complicações; Transplante de rim/fisiopatologia; Transplante de rim/tendências

\section{INTRODUCTION}

Cytomegalovirus (CMV) is a human virus from the Herpesviridae family, a $\beta$-Herpesvirus just as HHV-6 and HHV-7..$^{(1)}$ It is the largest known human herpesvirus, with 150 to $200 \mathrm{~nm}$ in diameter, and is formed by a capsid of 162 proteins, an envelope that contains

\footnotetext{
Hospital Israelita Albert Einstein, São Paulo, SP, Brazil.

2 Universidade Federal de São Paulo, São Paulo, SP, Brazil.

Corresponding author: Lucio Roberto Requião Moura - Transplantation Unit, Hospital Israelita Albert Einstein - Rua Monsenhor Henrique Magalhães, 96 , casa II laranja, 10 andar - Morumbi Zip code: 05653-110 - São Paulo, SP, Brazil - Phone: (55 11) 2151-0432 - E-mail: Irequiao@einstein.br
}

Received on: May 5, 2014 - Accepted on Feb 26, 2015

DOI: 10.1590/\$1679-45082015RW3175 
lipoproteins and at least 33 structural proteins, of which $\beta$-glycoprotein is the most important, and the core, with a double strand of DNA $(64 \mathrm{~nm}){ }^{(1-3)}$ In general, the first infection occurs in childhood, and seroprevalence is 70 to $90 \%$ of the adult population. ${ }^{(4,5)}$ After the first infection, the presence of the virus may be identified in subpopulations of CD34+ myeloid progenitors as well as in CD14+ monocytes, dendritic cells, and megakaryocytes. ${ }^{(6,7)}$ In situations of immunosuppression, such as AIDS (acquired immunodeficiency syndrome) and in solid organ transplants, CMV reactivation may occur, causing a varied spectrum of clinical manifestations. ${ }^{(6)} \mathrm{CMV}$ infection is the primary infectious complication in kidney transplantation, and it is one reason for high morbidity and mortality rates. ${ }^{(2)}$

\section{OBJECTIVE}

To present a review of the main clinical aspects of cytomegalovirus infection in renal transplants with a focus on clinical approach and its future perspectives.

\section{METHODS}

The present article was a critical and narrative review study based on relevant articles published about CMV infection in renal transplants. For review of the theme, the most relevant publications were selected based on PubMed, using as source for research descriptors such as "cytomegalovirus infection" and "kidney transplantation". Previously published review articles were selected as well as studies designed to assess the following subthemes: clinical aspects, comparative studies of diagnostic methods that evaluated antigenemia or polymerase chain reaction (PCR), resistance to ganciclovir, and immunological monitoring. Additionally, data were presented from a longitudinal prospective cohort study that assessed the prevalence of CMV infection and the risk factors for its occurrence in 209 patients submitted to kidney transplants from cadaver donors at the Kidney Transplant Unit of Hospital Israelita Albert Einstein between 2002 and 2012.

\section{Clinical aspects}

In transplants, infection may occur as a primo-infection or as reactivation after a long latency period. In all the candidates for kidney transplants, as well as in all the donors, the serological status should be established by means of identifying IgG class antibodies. ${ }^{(3)}$ A study that evaluated more than 20 thousand transplanted patients found the following distribution of serological matchings as to the $\operatorname{IgG}$ status $(\mathrm{D}=$ donor and $\mathrm{R}=$ recipient $)$ : $\mathrm{D}+/ \mathrm{R}+=47.7 \%, \mathrm{D}-/ \mathrm{R}+=24.1 \%, \mathrm{D}+/ \mathrm{R}-18.2 \%$, and $\mathrm{D}-/ \mathrm{R}-=10.3 \%$. $^{(5)}$ The serological status is a long-term prognostic marker regardless of the development of the disease. When $\mathrm{D}+/ \mathrm{R}$ - are compared with $\mathrm{D}-/ \mathrm{R}-$, there is a $28 \%$ increase in risk of graft loss, $36 \%$ in the risk of death due to all causes, and eight-fold the risk of dying by a viral infection. Serological typing, therefore, is indicated for all donors and recipients. ${ }^{(4-6)}$

Primo-infection occurs in D+/R- recipients, in whom the viral infection is transmitted by the transplanted organ. ${ }^{(3-7)}$ In recipients that carry the virus there may be viral reactivation, and the primary risk factors identified are the use of anti-lymphocyte antibodies (ALA), the type of immunosuppression protocol used (type of drug, dose and duration), the treatment of acute rejection, and a few factors related to the recipient, such as age, co-morbidities, and the development of neutropenia. ${ }^{(8,9)}$ Reactivation is related to reduction of cellular immune activity, especially of CD8+ cells, as result of the immunosuppressed state, and also due to activity of cytokines that induce the virus to move from the state of latency, especially tumor necrosis factor alpha (TNF- $\alpha$ ) and interleukin-1 $\beta$ (IL-1 $\beta$ ). ${ }^{(7-11)}$ The use of ALA, besides causing intense and prolonged lymphopenia, is related to the release of cytokines, especially TNF- $\alpha .^{(3-7)}$ Acute rejection, in addition to requiring intensification of immunosuppression, causes an increased expression of IL-1 $\beta$, which is a cytokine that stimulates viral replication (Figure 1). ${ }^{(7)}$

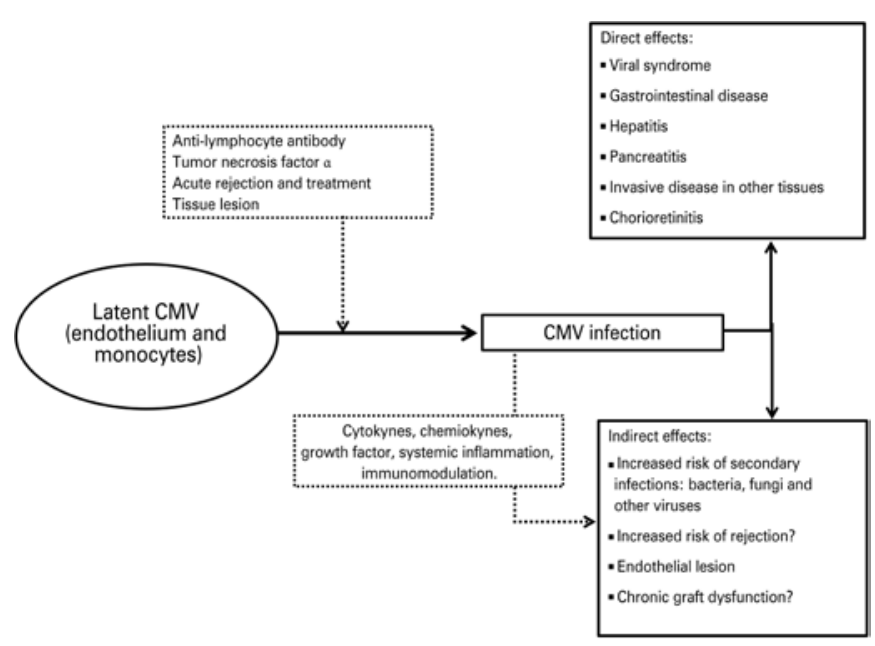

TNF-a: tumor necrosis factor alpha; CMV: cytomegalovirus.

Figure 1. Spectra of cytomegalovirus infection in transplant 
After the occurrence of viral activation (whether in primo-infection or reactivation), an infection by CMV may be classified in two ways, according to its clinical presentation as infection or disease. ${ }^{(12,13)}$ In CMV infection, there is evidence of viral replication in the absence of symptoms. This presentation is different from latency, because in latency there is no evidence of active viral replication. On the other hand, CMV disease is characterized by the clinical syndrome in which there are symptoms, such as fever, asthenia, myalgia, leukopenia, thrombocytopenia, or hepatic enzyme alterations, or by the invasive disease, in which there is evidence of viral inclusion in cells of organs or tissues, such as in the gastrointestinal tract, liver, in the renal graft, lungs, bone marrow and retina. The effects of CMV infection can be classified as direct or indirect (Figure 1). The direct effects are infection and disease, as mentioned above. The indirect effects observed are increased risk of secondary infections, such as pneumocystosis and other herpesviruses, and increased risk of acute rejection and of chronic graft dysfunction. ${ }^{(7)} \mathrm{CMV}$ infection can trigger a general immunostimulatory response, with concomitant antigenic stimulation. Hence, CMV has always been considered a potential risk factor for acute rejection of grafts, especially in lung transplants. In a study with 477 patients with transplanted kidneys, with a $38 \%$ prevalence of acute rejection confirmed by biopsy, $64 \%$ of infection by CMV, and $24 \%$ of disease, the authors observed that infection and the disease by CMV increased the risk of acute rejection by 1.6- and 2.5-fold, respectively. ${ }^{(11)}$

There is evidence that CMV may be related to chronic vascular alterations and can influence the development of bronchiolitis obliteratens in lung transplants, accelerated coronary artery disease in heart transplants, and chronic vascular disease in kidney transplants. ${ }^{(14-16)}$ The impact of the indirect effects of CMV in several renal compartments is the object of speculation. Reischiget et al. demonstrated that viremia by CMV measured by PCR was related to the increased risk of interstitial fibrosis and tubular atrophy (IF/TA) in protocol biopsies, 3 months after the kidney transplant. ${ }^{(17)}$ In this study, however, patients who had chronic alterations were those who had more acute rejection, but it was not possible to associate CMV infection with an inducing factor of fibrosis.

In the kidney transplant program of Hospital Israelita Albert Einstein, a total of 209 kidney transplanted patients with deceased donors were evaluated in a consecutive manner for one decade. They were all induced with thymoglobulin (an ALA), and therefore with risk of developing the infection. Only $11.5 \%$ of the recipients had $\mathrm{IgG}$ negative for CMV before transplant.
The prevalence of CMV infection among these patients was $63.4 \%$, and when the characteristics of the patients who had infection were compared to those who did not have infection (Table 1), we only observed a greater time of cold ischemia among those who had the infection $(22.9 \pm 5.7$ versus $21.2 \pm 5.9$ hours; $p=0.03)$. The time to diagnosis of the infection was $45.0 \pm 15.6$ days, and of these, 11 patients presented with it 3 months after transplant, with a prevalence of late infection of $7.3 \%$. As to the clinical picture, $43.7 \%$ had infection and $52.3 \%$, disease; of these, $9.3 \%$ had invasive disease (Figure 2). The diagnosis was performed with a mean of 80.0 136.0 infected cells in pp65 antigenemia. One single episode of infection occurred in $55.8 \%$ of patients, at least one relapse in $33.3 \%$, and more than one relapse in $10.9 \%$ (Figure 2 ).

Table 1. Clinical characteristics of 209 transplant recipients from cadaver donors, according to the cytomegalovirus infection, in the Transplant Program of Hospital Israelita Albert Einstein

\begin{tabular}{lcccc}
\hline Variables & $\begin{array}{c}\text { Total } \\
\text { (n=209) }\end{array}$ & $\begin{array}{c}\text { CMV } \\
\text { positive } \\
\text { (n=145) }\end{array}$ & $\begin{array}{c}\text { CMV } \\
\text { negative } \\
\text { (n=64) }\end{array}$ & p-value \\
\hline Age (years) & $45.4 \pm 13.6$ & $45.6 \pm 14.2$ & $45.1 \pm 12.2$ & 0.48 \\
Male recipient (\%) & 54.5 & 55.9 & 52.9 & 0.90 \\
Time in RST (months) & $56.5 \pm 43.4$ & $58.0 \pm 44.3$ & $53.0 \pm 41.4$ & 0.48 \\
Negative lgG-CMV (\%) & 11.5 & 12.6 & 9.4 & 0.97 \\
Positive lgG-CMV title (IU/mL) & $58.4 \pm 66.9$ & $59.7 \pm 70.1$ & $55.2 \pm 59.0$ & 0.55 \\
Mismatches (n) & $2.8 \pm 1.4$ & $2.9 \pm 1.4$ & $2.8 \pm 1.4$ & 0.65 \\
Age of donor (years) & $38.8 \pm 13.3$ & $39.9 \pm 13.3$ & $36.3 \pm 13.1$ & 0.07 \\
Male donor (\%) & 53.1 & 55.2 & 48.5 & 0.64 \\
Time of cold ischemia (hours) & $22.4 \pm 5.8$ & $22.9 \pm 5.7$ & $21.2 \pm 5.9$ & 0.03 \\
Doses of thymoglobulin (n) & $5.3 \pm 2.9$ & $5.3 \pm 2.9$ & $5.3 \pm 2.9$ & 0.93 \\
Tacrolimus (\%) & 76.1 & 80 & 69.1 & 0.56 \\
Cyclosporine (\%) & 20.6 & 17.9 & 25 & 0.36 \\
\hline RST: renal substitution therapy: CMV: cytomegalovirus. & & &
\end{tabular}

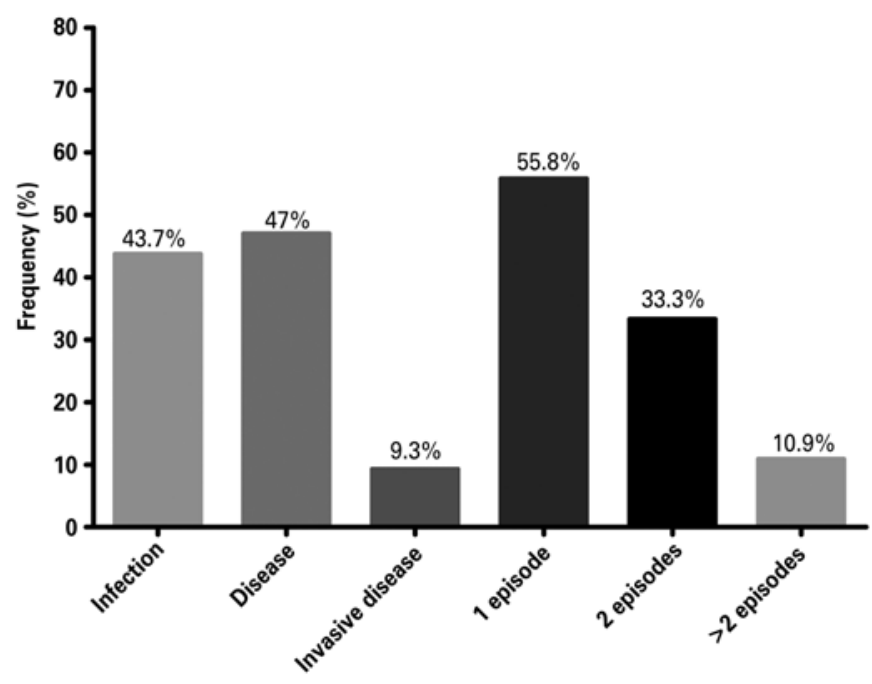

Figure 2. Clinical presentation and need for retreatment of cytomegalovirus infection in the Kidney Transplant Program of the Hospital Israelita Albert Einstein 


\section{DIAGNOSIS: ANTIGENEMIA AND PCR}

Histopathology, serology (IgM) and cell cultures were frequently used in the past for diagnosis of CMV, but should no longer be utilized due to their low sensitivity and technical difficulties. ${ }^{(12,13)}$ Histopathology requires tissue biopsies, and despite being definitive when the viral inclusions are found, it is not very sensitive and only allows the diagnosis of invasive disease. ${ }^{(3)}$ It may be useful in clinically suspect cases when viremia is negative. The detection of IgM should not be used for diagnosis of active infection in transplants because the titles of $\operatorname{IgM}$ are not detected early, because they are related to the late initiation of treatment. Cell cultures present good sensitivity, indicating CMV activity when positive, but requiring 1 to 3 weeks for confirmation of a negative result. ${ }^{(3-7)}$

The most sensitive and recommended methods for diagnosis are based on viral load, and can be performed by pp65 antigenemia or PCR. ${ }^{(18,19)}$ A positive viral load by one of these methods is an independent indicator of risk for CMV disease. Viremia is an indispensable tool for initiating and following up treatment. During viral replication, three types of antigens are produced: immediate, early, and late. ${ }^{(20)}$ Immediate antigens appear in the nucleus of the infected cells 1 to 3 hours after infection, and persist during the latent infection. The early antigens appear in the cytoplasm 3 hours after infection, even before the beginning of DNA synthesis. The late antigens are structural proteins and only appear after the synthesis of DNA, and therefore are associated with active infection. One of the late agents is pp65 antigen and can be identified within the cytoplasm of leukocytes by immunofluorescence, a technique called "pp65 antigenemia". ${ }^{(19-23)}$ This method has the advantage of being quick, with results given on the same day of collection, but it requires a trained team and its sensitivity is reduced if the blood is processed after 6 hours.

The gold standard for diagnosis of CMV is the quantitative nucleic acid testing (QNAT). QNAT-CMV has been performed preferentially by real time PCR (RT-PCR), using plasma or total blood. The qualitative standard indicates CMV in activity, but has no direct relation with the presence of the disease, which requires quantification. Therefore, the viral load detected by PCR has high predictive power for the disease and should be preferred. Contrary to antigenemia, sensitivity is not altered by blood storage, and can be transported for its use in distant centers. Its disadvantages are the lack of standardization among the centers, with discordance as to the results under inter-center analysis and need for greater time to perform, when compared to antigenemia. ${ }^{(24-27)}$

\section{RISK REDUCTION AND INFECTION TREATMENT STRATEGY}

Two strategies of risk reduction for the CMV disease are currently available and should be adopted in highrisk patients: preemptive treatment and universal prophylaxis. ${ }^{(4,6,12,13)}$ High-risk patients are considered those with a serological match $\mathrm{D}+/ \mathrm{R}$ - or those who received some kind of ALA treatment. The positive $\mathrm{IgG}$ recipients are considered of intermediate risk and may also benefit from one of the strategies. Universal prophylaxis consists in the administration of an antiviral for the period of 3 to 6 months. Current evidence demonstrates that the use of valaciclovir is not adequate for prophylaxis, and ganciclovir (orally) and valganciclovir are used. In addition to the prolonged exposure to the drug, which may increase the risk of resistance and side effects, universal prophylaxis is associated with the late onset disease, with an incidence of up to $18 \%$ after discontinuation of the medication. The preemptive treatment consists of intense monitoring of viremia, weekly between the $21^{\text {st }}$ and the $90^{\text {th }}$ postoperative days (and can be continued for more time depending on the progression of the patient and intensity of the immunesuppression), initiating treatment with intravenous ganciclovir or valganciclovir in patients with positive viremia. Besides lower cost and less exposure to the drug, the preemptive treatment is associated with a lower risk of late onset disease. One potential disadvantage of this strategy is that it allows exposure to viremia more frequently than prophylaxis, which would not avoid the indirect effects of the virus; however, comparative studies showed that viremia may also occur during prophylaxis, but with less prevalence.

The treatment of CMV infection should be done with intravenous ganciclovir for 14 to 28 days. Asymptomatic patients or those with disease, but with no severity criteria, can be treated with valganciclovir. If the investigation of viremia is done with antigenemia, we suggest maintaining the treatment for 1 week after obtaining negative result, since that is the period in which PCR persists as positive. Patients with invasive disease should be treated for 21 to 28 days. In children, or in cases of the first infection, as well as in patients with low doses of immunoglobulins, one can use polyclonal immunoglobulin or the one specific against CMV, as adjuvant treatments.

\section{RESISTANCE INVESTIGATION}

Since both universal prophylaxis and preemptive treatment have exposed the patients to frequent and prolonged use of ganciclovir, there is a risk of CMV developing resistance to the drug (CMV-R). Besides 
the prolonged use of the antiviral, the serological D+/Rmatch and the late viral eradication after initiating treatment are mentioned as the primary risk factors for developing resistance. ${ }^{(28)}$ Resistance is caused by mutation in two genes, UL97 and UL54, and the former is the most important and the most frequent. The incidence of CMV-R reaches $20 \%$ in AIDS patients with retinitis after 9 months of treatment, and can be related to time of exposure to the drug. ${ }^{(29)}$ In a study that evaluated 1,244 kidney transplant recipients, Myhre et al. identified resistance to ganciclovir in 27 patients (2.2\%); in that, 26 had the serological match D+/R-. ${ }^{(30)}$ Treatment of CMV-R may be done with high doses of intravenous ganciclovir (up to $10 \mathrm{mg} / \mathrm{kg} / \mathrm{dose}$ ), or more appropriately, with foscarnet or cidofovir. The limitation for use of these last two drugs is their potential renal toxicity. Câmara et al. assessed a series of nine patients with kidney or pancreas-kidney transplants with CMV-R, in which the calcineurin inhibitor or mycophenolate was substituted by sirolimus, an inhibitor of mammalian target of rapamycin (mTOR). Treatment with ganciclovir was maintained and among these patients only one required the use of foscarnet, demonstrating that mTOR inhibitors can have an adjunctive function in treating infection by CMV-R. ${ }^{(31)}$

\section{PERSPECTIVE: IMIMUNOLOGIC MONITORING}

After transplant, a few immune markers may be used to define patients with greater sensitivity for infection, and lately, the determination of these markers by means of sophisticated laboratorial tests has become a frequently used tool in research and should reach clinical practice within the next few years. ${ }^{(12,13)}$ There are lines of research with promising results both in innate immunity markers and in cell adaptive immunity.

Natural killer (NK) cells, components of the innate immune system, play an important role in virus clearance in experimental models of CMV infection. Mice with NK ablation are susceptible to lethal infection. Adult mice resistant to CMV infection become sensitive when they are depleted of NK cells. ${ }^{(32)}$ Patients with deficiency in NK cells present with recurring herpetic infection, including pneumonitis due to CMV. In a study with 43 patients submitted to bone marrow transplants that presented with CMV reactivation, the capacity to recover from the infection was associated with the activity of the NK cells. ${ }^{(33)}$

Another component of the innate immune system that can be related with CMV infection is the third pathway of the complement. This via, called "mannose-binding lecithin" (MBL), is activated by MBL itself, which has characteristics similar to the $\mathrm{C} 1 \mathrm{q}$ molecule, with four subunits denominated MASP (MBL - associated serine protease). Through MASP 1 and 2, the C2 and $\mathrm{C} 4$ fractions of the complement are cleaved to $\mathrm{C} 3$ convertase, thus activating the common pathway. ${ }^{(34)}$ This pathway seems to play an important role in the innate response of immunosuppressed children and individuals. Circulating MBL is organized into oligomeric structures, facilitating multivalent bonding with microbial components. MBL2 polymorphism can produce a defective MBL in the polymerization process, and is associated with low serum levels and reduction of its activity. ${ }^{(35)} \mathrm{MBL}$ deficiency is related to recurring meningitis by HSV-2, symptomatic genital herpes, susceptibility to HIV infection, as well as the earlier development of AIDS in infected patients, to meningococcal disease and to bacterial infections in liver transplant. ${ }^{(36-38)}$ In a study performed in patients with transplanted kidneys, Manuel et al. identified that the serum levels of MBL were significantly lower in patients who had CMV infection $(2.445 \mathrm{mg} / \mathrm{mL}$ versus $97 \mathrm{mg} / \mathrm{mL} ; \mathrm{p}=0.004$; cutoff point at $500 \mathrm{mg} / \mathrm{mL}$ ). In this same study, in which all the individuals included were $\mathrm{D}+/ \mathrm{R}-$, the deficiency was diagnosed in $71 \%$ of cases of invasive disease, while there was no patient with the deficiency among those who did not present with the infection after transplant, despite the high-risk serological match. ${ }^{(39)}$

Adaptive response activity can also be measured. ${ }^{(40)}$ In an elegant study, Radha et al., described that after the primo-infection, CMV leaves its digital impression in pools of $\mathrm{CD} 8+$ and $\mathrm{CD} 4+\mathrm{T}$-cells. The response of these cells in the presence of certain antigens of the CMV can be measured by a few methods, such as major histocompatibility complex (MHC) tetramers, Enzyme-Linked ImmunoSpot (ELISPOT), and flow cytometry of cytokines, the latter of which is the most frequently used. When $\mathrm{CD} 4+$ and $\mathrm{CD} 8+$ cells of patients who have already had the infection are treated with lysates of antigens such as pp65 and EI, the pool of specific cells against CMV can be identified through the quantity of interferon-gamma (IFN- $\delta$ ) produced. In a study that evaluated 108 patients transplanted with solid organs, with prevalence of infection of $16.7 \%$, Humar et al. described measuring activity of the immune system (cell-mediated immunity - CMI) specific against CMV falls significantly soon after the transplant and then progressively increases in the subsequent months. ${ }^{(3)}$ During pre-transplant, approximately $50 \%$ of the patients had positive CMI, which occurred in only $15.7 \%$ and $27.6 \%$ in the first and third months after the transplant, respectively. The capacity for recovery from 
CMI was related to the risk of developing infection. The frequency of CMV disease was $20 \%$ among the patients with negative CMI, whereas in those with positive CMI, it was less than $5 \%(\mathrm{p}=0.04)$.

\section{CONCLUSIONS}

Cytomegalovirus infection is one of the main infectious morbidities after renal transplant, leading to direct effects, such as disease, characterized by the viral syndrome or by the invasive disease, and to indirect effects, such as increased risk of acute rejection and chronic graft dysfunction. The diagnosis should be made proactively, using sensitive forms of viremia identification: antigenemia or polymerase chain reaction. One emergent problem in managing patients with cytomegalovirus is infection resistant to ganciclovir, which may be treated with other antivirals or with mTOR-inhibitors. Immunologic monitoring plays a promising role in identifying patients with the potential of progressing in an unfavorable manner and it is a tool that should be added to clinical practice on a large scale.

\section{REFERENCES}

1. Pass FR. Epidemiology and transmission of cytomegalovirus. J Infect Dis. 1985; 152(2):243-8. Review.

2. Brennan DC. Cytomegalovirus in renal transplantation. J Am Soc Nephrol. 2001;12(4):848-55. Review.

3. Humar A, Snydeman D; AST Infectiuos Diseases Community of Pratice. Cytomegalovirus in solid organ transplant recipients. Am J Transplant. 2009;9 Suppl 4:S78-86.

4. Kasiske BL, Zeier MG, Chapman JR, Craig JC, Ekberg H, Garvey CA, Green MD, Jha V, Josephson MA, Kiberd BA, Kreis HA, McDonald RA, Newmann JM, Obrador GT, Vincenti FG, Cheung M, Earley A, Raman G, Abariga S, Wagner M, Balk EM; Kidney Disease: Improving Global Outcomes. Clinical practice guideline for the care of kidney transplant recipients: a summary. Kidney International. 2010;77(4):299-311.

5. Kuo HT, Ye X, Sampaio MS, Reddy P, Bunnapradist S. Cytomegalovirus serostatus pairing and deceased donor kidney transplant outcomes in adult recipients with antiviral prophylaxis. Transplantation. 2010;90(10):1091-8.

6. Paya CV. Prevention of cytomegalovirus disease in recipients of solid-organ transplants. Clin Infect Dis. 2001;32(4):596-603. Review.

7. Kotton CN, Fishman JA. Viral infection in the renal transplant recipients. J Am Soc Nephrol. 2005;16(6):1758-74. Review.

8. Ozaki KS, Pestana JO, Granato CF, Pacheco-Silva A, Camargo LF. Sequential cytomegalovirus antigenemia monitoring in kidney transplant patients treated with antilymphocyte antibodies. Transplant Infec Dis. 2004;6(2):63-8.

9. Asberg A, Jardine AG, Bignamini AA, Rollag $H$, Pescovitz MD, Gahlemann CC, Humar A, Hartmann A; VICTOR Study Group. Effects of the Intensity of Immunosuppressive Therapy on Outcome of Treatment for CMV Disease in Organ Transplant Recipients. Am J Transplant. 2010;10(8):1881-8.

10. Roayaie S, Sheiner PA, Emre S, Guy S, Schwartz ME, Boros P, et al. Cytokine profiles in early rejection following OKT3 treatment in liver transplant patients. Mediators Inflamm. 2000;9(3-4):141-6.

11. Sadegal $S$, Nordal KP, Hartmann A, Sund S, Scott H, Degré $M$, et al. The impact of cytomegalovirus infection and disease on rejection episodes in renal allograft recipients. Am J Transplant. 2002;2(9):850-6.
12. Kotton CN, Kumar D, Caliendo AM, Asberg A, Chou S, Snydman DR, Allen U, Humar A; Transplantation Society International CMV Consensus Group. International consensus guidelines on the management of cytomegalovirus in solid organ transplantation. Transplantation. 2010;89(7):779-95.

13. Kotton CN, Kumar D, Caliendo AM, Asberg A, Chou S, Danziger-Isakov L, Humar A; Transplantation Society International CMV Consensus Group. Updated international consensus guidelines on the management of cytomegalovirus in solid-organ transplantation. Transplantation. 2013;96(4):333-60.

14. Kroshus TJ, Kshettry VR, Savik K, John R, Hertz MI, Bolman RM 3rd. Risk factors for the development of bronchiolitis obliterans syndrome after lung transplantation. J Thorac Cardiovasc Surg. 1997;114(2):195-202.

15. Helanteräl, Koskinen P, Tõrnroth T, Loginov R, Gronhagen-RiskaC, Lautenschlager I. The impact of cytomegalovirus infections and acute rejection episodes on the development of vascular changes in 6-month protocol biopsy specimens of cadaveric kidney allograft recipients. Transplantation. 2003;75(11):1858-64.

16. Potena L, Valantine HA. Cytomegalovirus-associated allograft rejection in heart transplant recipients. CurrOpin Infect Dis. 2007;20(4):425-31. Review.

17. Reischig $T$, Jindra P, Hes O, Bouda M, Kormunda S, Treska V. Effect of cytomegalovirus viremia on subclinical rejection or interstitial fibrosis and tubular atrophy in protocol biopsy at 3 months in renal allograft recipients managed by preemptive therapy or antiviral prophylaxis. Transplantation. 2009;87(3):436-44

18. Rhee JY, Peck KR, Lee NY, Song JH. Clinical usefulness of plasma quantitative polymerase chain reaction assay: diagnosis of cytomegalovirus infection in kidney transplant recipients. Transplant Proc. 2011;43(7):2624-9.

19. Camargo LF, Uip DE, Simpson AA, Caballero O, Stolf NA, Vilas-Boas LS, et al. Comparison between antigenemia and a quantitative-competitive polymerase chain reaction for the diagnosis of cytomegalovirus infection after heart transplantation. Transplantation. 2001;71(3):412-7.

20. Gandhi MK, Khanna R. Human cytomegalovirus: clinical aspects, immune regulation, and emerging treatments. Lancet Infect Dis. 2004;4(12):725-38. Review.

21. Gerna G, Baldanti F, Lilleri D, Parea M, Torsellini M, Castiglioni B, et al. Human cytomegalovirus pp67 mRNAemia versus pp65 antigenemia for guiding preemptive therapy in heart and lung transplant recipients: a prospective, randomized, controlled, open-label trial. Transplantation. 2003;75(7):1012-9.

22. Schröeder R, Michelon T, Fagundes I, Bortolotto A, Lammerhirt E, Oliveira J, et al. Antigenemia for cytomegalovirus in renal transplantation: choosing a cut off for the diagnosis criteria in cytomegalovirus disease. Transplant Proc. 2005;37(6):2781-3.

23. Baldanti F, Lilleri D, Gerna G. Monitoring human cytomegalovirus infection in transplant recipients. J Clin Virol. 2008;41(3):237-41. Review.

24. LaoWC, LeeD, Burroughs AK, LanzaniG, RollesK, EmeryVC, etal. Use ofpolymerase chain reaction to provide prognostic information of human cytomegalovirus disease after liver transplantation. J Med Virol. 1997;51(3):152-8.

25. Caliendo AM, St George K, Allega J, Bullotta AC, Gilbane L, Rinaldo CR, et al. Distinguishing cytomegalovirus (CMV) infection and disease with CMV nucleic acid assays. J Clin Microbiol. 2002;40(5):1581-6

26. Rollag H, Sagedal S, Kristiansen KI, Kvale D, Holter E, Degré M, et al. Cytomegalovirus DNA concentration in plasma predicts development of cytomegalovirus disease in kidney transplant recipients. Clin Microbiol Infect. 2002; 8(7):431-4.

27. Razonable RR, van Cruijsen H, Brown RA, Wilson JA, Harmsen WS, Wiesner $\mathrm{RH}$, et al. Dynamics of cytomegalovirus replication during preemptive therapy with oral ganciclovir. J Infect Dis. 2003;187(11):1801-8.

28. Limaye AP, Corey L, Koelle DM, Davis CL, Boeckh M. Emergence of ganciclovirresistent cytomegalovirus disease among recipients of solid-organ transplant. Lancet. 2000;356(9230):645-50. Review.

29. Jabs DA, Martin BK, Forman MS, Dunn JP, Davis JL, Weinberg DV, Biron KK, Baldanti F; Cytomegalovirus Retinitis and Viral Resistance Study Group. Mutations conferring ganciclovir resistance in a cohort of patients with acquired immunodeficiency syndrome and cytomegalovirus retinitis. J Infect Dis. 2001;183(2):333-7. 
30. Myhre HA, Dorenberg DH, Kristiansen KI, Rollag H, Leivestad T, Asberg A, et al. Incidence and outcomes of ganciclovir-resistant cytomegalovirus infections in 1244 kidney transplant recipients. Transplantation. 2011;92(2):217-23.

31. Câmara NO, Ozaki KS, Nogueira E, Pereira MG, Granato C, Melaragno C, et tal. The use of sirolimus in ganciclovir-resistant cytomegalovirus infections in renal transplant recipients. Clinical Transplantation. 2007;21(5):675-80.

32. Polic B, Hengel H, Krmpotic A, Trgovcich J, Pavićl, Luccaronin P, et al. Hierarchical and redundant lymphocyte subset control precludes cytomegalovirus replication during latent infection. J Exp Med. 1998;188(6):1047-54.

33. Quinnan GV, Kirmani N, Rook AH, Manischewitz JF, Jackson L, Moreschi G, et al. Cytotoxic T cells in cytomegalovirus infection: HLA-restricted T-lymphocyte and non-T-lymphocyte cytotoxic responses correlate with recovery from cytomegalovirus infection in bone-marrow-transplant recipients. $\mathrm{N}$ Eng $\mathrm{J}$ Med. 1982;307(1):7-13.

34. Janeway CA, Travers P, Walport M, Shlomchik MJ. Munobiologia: o sistema imune na saúde e na doença. 6a ed. São Paulo: Artmed; 2006. Imunidade adaptativa contra infecção. p. 357-66
35. Madsen HO, Garred P, Kurtzhals JA, Lamm LU, Ryder LP, Thiel S, et al. A new frequent allele is the missing link in the structural polymorphism of the human mannan-binding protein. Immunogenetics.1994;40(1):37-44.

36. Hibberd ML, Sumiya M, Summerfield JA, Booy R, Levin M. Association of variants of the gene for mannose-binding lectin with susceptibility to meningococcal disease. Meningococcal Research Group. Lancet. 1999;353(9158):1049-53.

37. Peterslund NA, Koch C, Jensenius JC, Thiel S. Association between deficiency of mannose-binding lectin and severe infections after chemotherapy. Lancet. 2001;358(9282):637-8.

38. Bouwman LH, Roos A, Terpstra OT, de Knijff P, van Hoek B, Verspaget HW, et al. Mannose binding lectin gene polymorphisms confer a major risk for severe infections after liver transplantation. Gastroenterology. 2005;129(2):408-14.

39. Manuel O, Pascual M, Trendelenburg M, Meylan PR. Association between mannose-binding lectin deficiency and cytomegalovirus infection after kidney transplantation. Transplantation. 2007;83(3):359-62.

40. Radha R, Jordan S, Puliyanda D, Bunnapradist S, Petrosyan A, Amet N, et al Cellular immune response to cytomegalovirus in renal transplant recipients. Am J Transplant. 2005;5(1):110-7. 